GLOBAL WATER PATHOGEN PROJECT

PART FOUR. MANAGEMENT OF RISK FROM EXCRETA AND WASTEWATER

\title{
CESSPITS AND SOAKPITS
}

\section{Anthony A. Adegoke}

Durban University of Technology

Durban, South Africa

Thor-Axel Stenstrom

Durban University of Technology

Durban, South Africa 


\section{Copyright:}

\section{cc) (1) (2) \\ BY SA}

This publication is available in Open Access under the Attribution-ShareAlike 3.0 IGO (CC-BY-SA 3.0 IGO) license (http://creativecommons.org/licenses/by-sa/3.0/igo). By using the content of this publication, the users accept to be bound by the terms of use of the UNESCO Open Access Repository (http://www.unesco.org/openaccess/terms-use-ccbysa-en).

\section{Disclaimer:}

The designations employed and the presentation of material throughout this publication do not imply the expression of any opinion whatsoever on the part of UNESCO concerning the legal status of any country, territory, city or area or of its authorities, or concerning the delimitation of its frontiers or boundaries. The ideas and opinions expressed in this publication are those of the authors; they are not necessarily those of UNESCO and do not commit the Organization.

\section{Citation:}

Adegoke, A. and Stenstrom, T. 2019. Cesspits and Soakpits. In: J.B. Rose and B. Jiménez-Cisneros, (eds) Global Water Pathogen Project. http://www.waterpathogens.org (J.R. Mihelcic and M.E. Verbyla) (eds) Part 4 Management Of Risk from Excreta and Wastewater) http://www.waterpathogens.org/book/cesspits-andsoakpits Michigan State University, E. Lansing, MI, UNESCO. https://doi.org/10.14321/waterpathogens.58

Acknowledgements: K.R.L. Young, Project Design editor; Website Design: Agroknow (http://www.agroknow.com)

Last published: February 2, 2019 


\section{Summary}

A soak pit is a covered, porous-walled chamber that allows water to slowly soak into the ground. Soak pits, which can be lined with porous materials, which provide foundational support to prevent collapse of the underground chamber, may also be used for separate treatment of greywater. A cesspit (cesspool) is a holding tank (or pit) designed for collection and storage of sewage or other waste for short periods. Cesspits should be constructed watertight to better contain pathogens, however this is often not the case in practice. Two or more vent pipes are usually connected depending on the size of the cesspit, to reduce the possibilities of bringing odor back through the inlet pipes. Like cesspits, soak pits may be lined with concrete and may be closed or may have openings at the top to vent away odors. Soak pits generally serve as secondary chambers receiving effluent from a primary sanitation technology. Raw sewage should usually not constitute the input, but minimally pretreated blackwater or urine or faeces and greywater. Even though cesspits do not usually have outlets for effluent release to the surface, their effluents are intended to percolate into the surrounding soil, potentially leading to groundwater pollution. The outputs are essentially liquid, but the solids filtered by a soak pit may require removal from time to time in the case where the content of the soakpit chamber is reused. Some pathogens from leachates leaving a permeable cesspit may migrate through the soil matrix and be reduced in concentration to various extents depending on the type of pathogen, soil type, and geohydrological conditions. The largest risks of human exposure from contents discharged into a soak pit or cesspit occur 1) when emptying the pit contents, 2) through contamination of groundwater when used as a source of drinking water in proximity of the effluent leaving a soak pit, and 3) when a pit is overflowing due to system malfunctioning. Pretreatment of the influent entering a soak pit through sedimentation or filtration is important to mitigate against clogging or overflow and development of biofilm on the stones or pebbles that are placed inside a soak pit.

\subsection{Brief Technology Description}

A soak pit (also referred to as a soak-away) is a covered, porous-walled chamber that allows water to slowly soak into the ground (Figure 1). Soak pits serve as secondary chambers receiving effluent from a primary sanitation technology (e.g. septic tanks) for the treatment of wastewater (black water) and gradually allow the effluent to percolate into the surrounding soil. Soak pits may also be used for treatment of greywater (water from personal hygiene, like showering and from kitchen areas). The soak pit can be lined with porous materials (rocks, gravel, sand, wood, or highly adsorbing minerals such as aluminum silicate). These materials may also provide foundational support to prevent collapse of the underground chamber. Soak pits are sometimes left unlined and filled with coarse rocks and gravel. The rocks and gravel help prevent the chamber from collapsing and provide adequate space for the input of greywater and/or wastewater. They also create surface area for a biofilm to grow on (similar to what occurs in a trickling filter), although depending on the size of the material, this may not make much difference in the treatment efficiency. In both cases, a layer of sand and fine gravel (Figure 1) should be spread across the bottom to help disperse the flow (Eawag/Sandec, 2008; Tilley et al. 2014). A soak pit is often constructed to be 1.5 to $4 \mathrm{~m}$ deep, but it is recommended that the distance between the bottom of the soak pit and the groundwater table should be $\geq 2 \mathrm{~m}$ (Tilley et al., 2014). Design and construction of a soak pit used to manage greywater is provided elsewhere (Mihelcic et al., 2009).

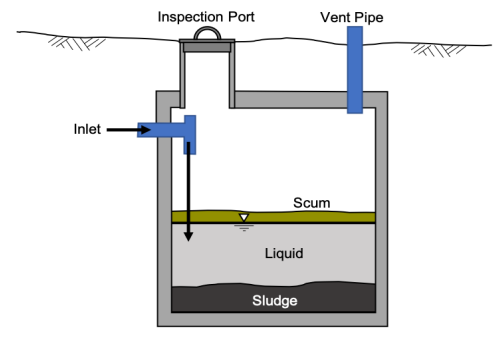

(a)

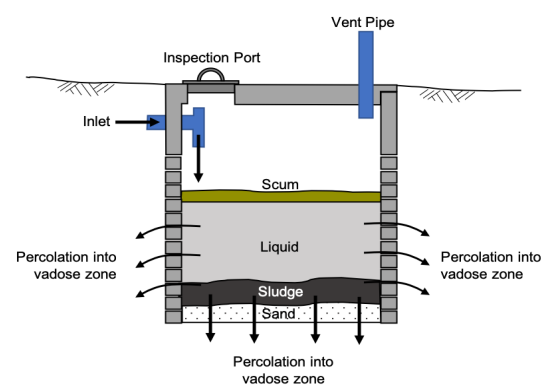

(b)

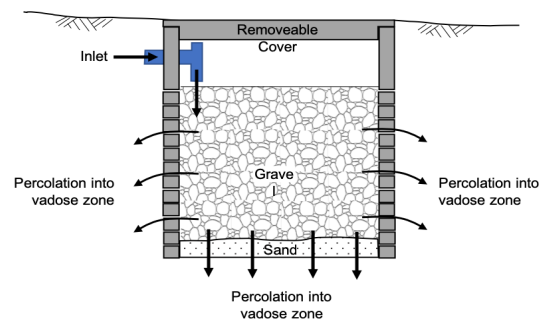

(c)

Figure 1. Schematic of (a) a watertight cesspit, (b) a cesspit, and (c) a typical soak-pit 
As the water percolates through the surrounding soil from the soak pit, small particles are filtered out by the soil matrix and organics are digested by microorganisms. Thus, soak pits are best suited in soils with good infiltration and absorptive properties. Hard-packed clay and rocky soils are not appropriate.

It is possible for a well-sized soak pit to last for 3 to 5 years without maintenance (Tilley et al., 2008). Maintenance involves excavation, cleaning and either washing and reclaiming the material or replacing new gravel, rock and sand (Tilley et al., 2008). The lifespan of a soak pit can be extended by filtering the influent to prevent accumulation of solids. Clogging of soak pits is expected after a period of time due to the removal of particles and the growth of biomass within the chamber. This clogging will eventually lead to failure of the system unless the chamber contents are emptied and cleaned or replaced.

A cesspit (cesspool) is a holding tank (or pit) designed for collection and storage of sewage or other waste for short periods of time (Figure 1). Cesspits should be manufactured to be watertight (e.g., lined with concrete or other non-permeable material) to fully contain the pathogens and reduce the possibilities of bringing odor back through the inlet pipes. Two or more vent pipes may be connected to the cesspit, and the pit may be either closed or slightly open (to vent away odors). Solids will settle and decay in the base as occurs within a septic tank. A watertight cesspit is expected to provide lower treatment and removal efficiencies than septic systems.
In reality, many cesspits are unlined or are constructed with permeable materials such as bricks or stone (Figure 1). In fact, cesspits have been directly associated with groundwater pollution, which makes it one of the least preferred onsite sanitation technologies (ARGOSS, 2001; Stenström et al., 2011). Even though cesspits do not have outlets for effluent discharge, their effluents may percolate into the surrounding soil, leading to groundwater pollution.

A cesspit is expected to serve only one household though it may be shared by families living in building that contains more than one toilet. The number of expected users determines the capacity of the tank to be installed which may range from 5 to $50 \mathrm{~m}^{3}$, depending on land availability. The number of users also determines the frequency of emptying the cesspit (Werner et al. 2000).

Both soak pits and cesspits are primarily used for onsite containment, collection, and treatment of human excreta. Soak pits and cesspit system fit within the overall sanitation service chain as depicted in Figure 2. As an alternative to the use of cesspits for greywater collection, Morel and Diener, (2006) suggested subsurface irrigation or surface trench irrigation of trees. Besides the advantage of providing water and nutrients for tree growth, this reuse is also a way of reducing the volume of effluent.
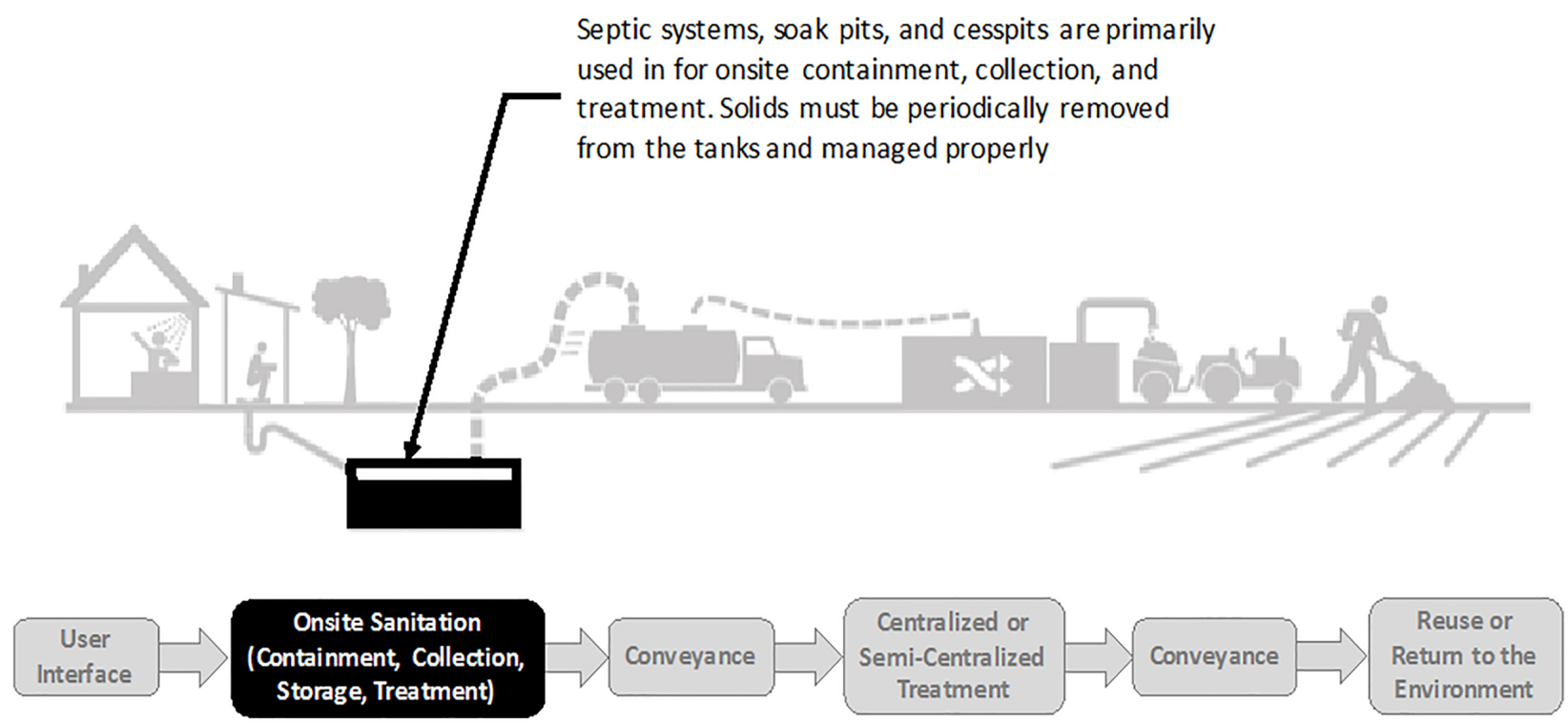

Figure 2. Schematic showing the position of soak pit and cesspit system in the sanitation service chain. This image is a derivative of "Sanitation Value Chain" by SuSanA Secretariat, which is licensed under CC BY

\author{
2.0.
}




\subsection{Inputs and Outputs of Soak Pits and Cesspits}

The ideal input to a soak pit should come from a sanitation system like a septic tank. Raw sewage should not constitute the input. Cesspit influent can include blackwater or urine or faeces, and greywater. The outputs are essentially liquid, though the solids filtered by a soak pit may require removal from time to time in the case where the content of the soakpit chamber is reused. The inputs and outputs of soak pits and cesspits are illustrated in Figure 3. It is possible to also link a septic tank with a cesspit, such that the cesspit receives the effluent from septic tank for further containment until it is ready for emptying. This is cheaper than a modified septic system (Anil and Neera, 2016).

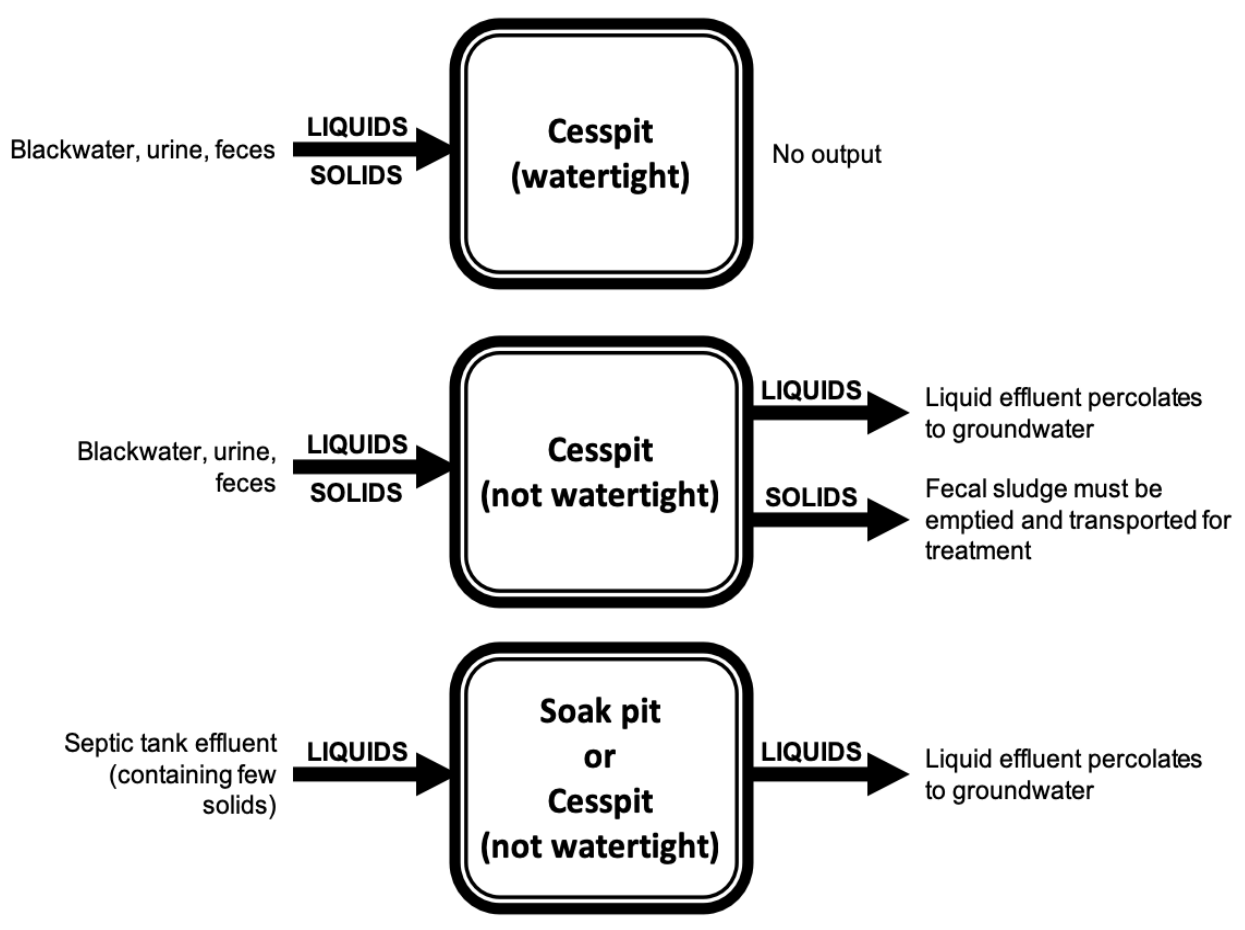

Figure 3. Illustrative inputs and outputs from (a) a watertight cesspit, (b) a non-watertight cesspit, and (c) a soak pit

Cesspits should not be constructed to be permeable unless a soil and groundwater assessment is done to demonstrate that the impact to groundwater will be minimal. Liquid will leach out from permeable cesspits (Grad, 2016), and some pathogens in this leachate may migrate through the soil matrix. Depending on the soil properties, the concentration of pathogens may be reduced as the leachate percolates through the soil. However, the extent of this reduction depends on the type of soil, moisture content, distance and other hydrogeological or environmental factors. Like a pit latrine, the fate of the pathogens leaving any sanitation related subsurface pit may impact well water; therefore, pathogen fate will depend on the soil's hydraulic conductivity and the distance between the bottom of the pit and the water source (Graham and Polizzotto, 2013). As the effluent leaches from a soak pit or the permeable cesspit and migrates through the unsaturated soil matrix, microorganisms can be removed (similar as in a conventional pit) (Tilley et al., 2008).

\subsection{Summary of Data and Factors Affecting Pathogen Reduction in a Soak Pit or Cesspit}

\subsection{Exposure Pathways}

The GWPP chapters on Onsite Pit Toilets and Septic Tanks provide information on the expected mechanisms that lead to fate and reduction of pathogens in the subsurface. The largest risk of human exposure from contents discharged to a soak pit and cesspit is through: 1) emptying of the pit contents, 2) contamination of groundwater used as a source of drinking water associated with the effluent leaving a soak pit, or 3) overflowing of a pit because of system malfunctioning. The risk of exposure is also potentially high during pit maintenance or after collection and conveyance of the pit contents. By following proper working conditions associated with management of the cesspit or soak pit, the associated human health risks (depending on the prevailing pathogens) via exposure to excreta can be lowered. However, cesspits may exhibit higher risks than soak pits because of more frequent emptying of the contents. There are also possibilities of infiltration when the surrounding soil is saturated, leading to the malfunction of the soak pit. This may also result in 
back-flow of the effluent to the surface exposing the users and community members to the wastewater. Furthermore, if a soak pit is constructed in an area with a high water table, the effluent will not be sufficiently processed as it passes through the soil matrix and may contaminate groundwater. There are unfortunately only a few reports on how soak pits and cesspits influence groundwater water quality, so it is difficult to draw major generalized conclusions on their use (Piranha et al., 2006; Vijay et al., 2011; Keegan et al., 2014).

\subsection{Mitigating the Risk of Pathogen Control in Soak Pits and Cesspits}

It is essential to ensure effective pretreatment of influent entering a soak pit (which may be in form of sedimentation or filtration to be removed or emptied) to prevent backups and overflows that may occur as a result of clogging of the soak pit chamber. As stated previously, clogging of a soak pit may occur from particles accumulating in the soak pit and development of biofilm on the stones or pebbles that are placed inside a soak pit. Pretreatment will reduce clogging, though this depends also on the site conditions. It is recommended that sanitation workers involved in excavating and changing the materials inside a soak pit or emptying the contents of a cesspit take proper hygiene precautions when emptying and conveying any pit contents. This should include wearing hand gloves, nose mask and all safety kits. The area should also be secluded from the passers-by due to possibility of infective aerosol that is accidentally released while emptying and spillages should be minimized. Furthermore, careful consideration of the local subsurface hydrology should be considered before building any sanitation technology that infiltrates to the soil. As mentioned previously, if the rate of infiltration through the soil is too high or if the bottom of the pit is close to a high groundwater table, then the risk of groundwater contamination is increased. If the rate of infiltration is too low, then the pit will not drain fast enough and may overflow, potentially causing surface water contamination.

\subsection{Epidemiological and Health Risk Evidence}

Theoretically, a soak pit that is correctly sited and designed so that groundwater contamination is minimized should result in low waterborne health concerns. Because of that the technology is located underground, humans and animals should have no contact with the effluent. However, as stated previously, a soak pit may cause microbiological contamination of groundwater (ARGOSS, 2001) and also poses direct exposure risk due to poor maintenance, siting, and during emptying (see further similar situations in the GWPP chapters on Onsite Pit Toilets and Septic Tanks).

The health risk is greater in areas with high human population densities that use these sanitation technologies or where permeable cesspits have been sited. In these cases, there have been reports of high risk of groundwater contamination (WHO, 1992). Setting up a specific guideline on siting is also difficult and should instead be considered in relation to the local detailed soil type and hydraulic conductivity conditions where the pits will be located. For example, Keegan et al. (2014) were able to track the source of contamination of underground water (in Ireland) by Microbial Source Tracking using Human-specific Bacteroidales as also used by several researchers including for example Kapoor et al. (2015). The authors measured concentrations of $535 \mathrm{GC} / 50 \mathrm{~mL}$ (GC refers to bacterial gene copy concentration and, in this case, representing Bacteroidales) in groundwater below a soak pit that received septic tank effluent. A nearby drilled well was also affected but to a slightly lesser extent (495 GCC/50 mL). This shows that the residents of the study area are likely exposed to the effluent from the septic tank and soak pit effluent because the Bacteriodales can be considered to be a fairly specific indicator of human fecal contamination. 


\section{References}

Anil, R. and Neera, A.L. (2016). Modified septic tank treatment system. Procedia Technology. 24, pp. 240-247.

ARGOSS (2001). Guidelines for assessing the risk to groundwater from on-site sanitation. British Geological Survey: Commissioned Report, CR/01/142. British Geological Survey. pp. 97.

EAWAG/SANDEC (2008). Sanitation Systems and Technologies: Sandec Training Tool 1.0 - (2008) Module 4.

Franceys, R., Pickford, J. and Reed, R. (1992). A guide to the development of on-site sanitation. World Health Organization. Geneva, Switzerland.

Grad, M. (2016). Collection and treatment of fecal disposal in rural areas of developing countries. Civil Engineering, Geotechnical and Hydraulic Engineering. Masters, Graz University of Technology. Styria, Austria. pp. 167.

Graham, J.P. and Polizzotto, M.L. (2013). Pit latrines and their impacts on groundwater quality: a systematic review. Environmental Health Perspectives. 121, pp. 521.

Kapoor, V., Pitkanen, T., Ryu, H., Elk, M., Wendell, D. and Domingo, J.W.Santo (2015). Distribution of human-specific bacteroidales and fecal indicator bacteria in an urban watershed impacted by sewage pollution, determined using RNAand DNA-based quantitative PCR assays. Applied Environmental Microbiology. 81(1), pp. 91-9. doi: 10.1128/AEM.02446-14.

Keegan, M., Kilroy, K., Nolan, D., Dubber, D., Johnston, P.M., Misstear, B.D.R. et al. (2014). Assessment of the impact of traditional septic tank soakaway systems on water quality in Ireland. Water Science and Technology. 70, pp. 634-641.

Mihelcic, J.R., Fry, L.M., Myre, E.A., Phillips, L.D. and Barkdoll, B.D. (2009). Field guide to environmental engineering for development workers: water, sanitation, and indoor air. American Society of Civil Engineers.

Morel, A. and Diener, S. (2006). Greywater management in low and middle-income countries, review of different treatment systems for households and neighbourhood. Sandec report No. 14/06. Swiss Federal Institute of Aquatic Science and Technology (Eawag). Dübendorf, Switzerland. pp. 107.

Piranha, J.M., Pacheco, A., Gamba, R.C., Mehnert, D.U., Garrafa, P. and Barrella, K.M. (2006). Faecal Contamination (Viral and Bacteria) Detection in Groundwater used for Drinking Purposes in São Paulo, Brazil. Geomicrobiology Journal. 23, pp. 279-283.

Stenström, T.A., Seidu, R., Ekane, N. and Zurbrügg, C. (2011). Microbial exposure and health assessments in sanitation technologies and systems. Stockholm Environment Institute (SEI) Stockholm.

Tilley, E., Ulrich, L., Lüthi, C., Reymond, P. and Zurbrügg, C. (2014). Compendium of Sanitation Systems and Technologies. 2nd Revised Edition. Swiss Federal Institute of Aquatic Science and Technology (Eawag). Dübendorf, Switzerland.

Tilley, E. (2008). Compendium of sanitation systems and technologies. Eawag.

Vijay, R., Khobragade, P. and Mohapatra, P.K. (2011). Assessment of groundwater quality in Puri City, India: an impact of anthropogenic activities. Environmental Monitoring and Assessment. 177, pp. 409-418.

Werner, C., Schlick, J., Witte, G. and Hildebrandt, A. (2000). Ecosan closing the loop in wastewater management and sanitation. Eschborn: The Deutsche Gesellschaft für Internationale Zusammenarbeit (GIZ) GmbH. Germany. 